\title{
Reproductive strategies in black scabbardfish (Aphanopus carbo Lowe, 1839) from the NE Atlantic
}

\author{
ANA NEVES ${ }^{1}$, ANA RITA VIEIRA ${ }^{1}$, INÊS FARIAS ${ }^{2}$, IVONE FIGUEIREDO ${ }^{2}$, \\ VERA SEQUEIRA $^{1}$ and LEONEL SERRANO GORDO ${ }^{1}$ \\ ${ }^{1}$ Departamento de Biologia Animal and Centro de Oceanografia, Faculdade de Ciências da Universidade de Lisboa, \\ Bloco C2, Campo Grande, 1749-016 Lisboa, Portugal. E-mail: amneves@ fc.ul.pt \\ ${ }^{2}$ Unidade de Recursos Marinhos e Sustentabilidade, IPIMAR, Av. Brasília, 1449-006 Lisboa, Portugal.
}

\begin{abstract}
SUMMARY: Gonads of the NE Atlantic black scabbardfish were examined to give an insight into the reproductive biology of this species. It was concluded that black scabbardfish had determinate fecundity because: (i) a distinct hiatus in oocyte size was observed between pre-vitellogenic and vitellogenic oocytes; (ii) vitellogenic oocytes increased in size during the spawning season; (iii) the number of vitellogenic oocytes did not increase during the spawning season; and (iv) the intensity of atresia was low in pre-spawning and spawning ovaries. Fecundity estimates ranged from 73 to 373 oocytes g ${ }^{-1}$ female. Comparison of developing ovaries from mainland Portugal and Madeira revealed that those from Madeira were more advanced in development, with more cortical alveoli stage oocytes and a higher gonadosomatic index. Starting in July, the reproductive development of all females from mainland Portugal was interrupted by a generalised atresia of developing oocytes. Completion of gametogenesis and spawning only occurred for fish from Madeira but some fish from this area also failed to complete oocyte development due to mass follicular atresia of vitellogenic oocytes. The percentage of Madeiran fish that failed to spawn due to follicular atresia ranged from $21.2 \%$ in 2006 to $37.4 \%$ in 2005 .
\end{abstract}

Keywords: black scabbardfish, skipped spawning, fecundity, atresia, Portugal.

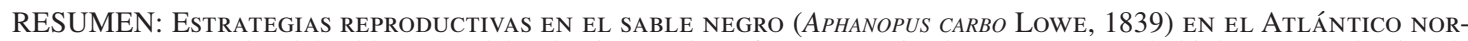
DESTE. - Las gónadas del sable negro del Atlántico nordeste fueron examinadas para conocer la biología reproductiva de esta especie. Los resultados sobre el tipo de fecundidad mostraron que la especie tenía una fecundidad determinada en base a los siguientes hechos: (i) hiato entre ovocitos previtelogénicos y vitelogénicos; (ii) aumento de tamaño de los ovocitos vitelogénicos durante el período de puesta; (iii) ausencia de incremento en el número permanente de ovocitos vitelogénicos avanzados durante el período de puesta y (iv) una pequeña atresia en los ovarios antes de la ovulación y durante ella. Las estimaciones de fecundidad se establecieron entre 73 y 373 ovocitos $\mathrm{g}^{-1}$ hembra. La comparación de los ovarios de hembras en desarrollo de aguas frente a Portugal continental y las de Madeira mostró una diferencia significativa en el tamaño medio de los ovocitos entre las dos áreas, y que las hembras de Madeira presentaron una mayor cantidad de ovocitos con alvéolos corticales y un índice gonadosomático mayor. A partir de julio y en hembras recolectadas frente a Portugal de continente, todos los individuos comenzaron a sufrir una atresia generalizada en sus ovocitos, mientras que en las aguas de Madeira, el ciclo reproductivo continúa hasta ovulación. Sin embargo, en algunas hembras de Madeira la gametogénesis también se paraliza y todos los ovocitos vitelogénicos son absorbidos vía atresia folicular. El porcentaje de hembras no reproductivas varió del $21.23 \%$ en 2006 al $37.4 \%$ en 2005.

Palabras clave: sable negro, skip spawning, fecundidad, atresia, Portugal.

\section{INTRODUCTION}

Most teleost marine fish species of commercial importance are iteroparous and gonochoristic, pos- sess no sexual dimorphism, exhibit external fertilisation without parental care and release a large number of pelagic eggs (Murua and Saborido-Rey, 2003). These characteristics are part of the repro- 
ductive strategies that fish species follow in order to maximise reproductively active offspring in relation to available energy and parental life expectancy (Pianka, 2000).

The study of fish reproduction is fundamental for understanding/predicting population dynamics, for improving the management of the assessed stock (using the reproductive information needed for assessment models) and for stock identification studies. Regarding the latter, a multitude of reproductive life-history traits has been used to provide the basis for stock differentiation, including timing, duration and location of spawning (Begg, 1998); egg size and fecundity relationships (Marteinsdottir et al., 2000); and reproductive potential (Trippel, 1999).

The black scabbardfish (Aphanopus carbo Lowe, 1839) is a widely distributed deep-water species that occurs in the NE Atlantic from Iceland to Madeira Island (Tucker and Palmer, 1949; Gordon, 1986; Merrett et al., 1991). Despite the increasing commercial interest in this species, little is known about its life cycle. Egg and larval stages of the black scabbardfish are unknown and juvenile fish are seldom caught (Swan et al., 2003). Immature individuals predominate to the west of the British Isles, while larger but non-reproductive individuals are present off mainland Portugal (Figueiredo et al., 2003). Ripe individuals are only caught in Madeiran waters during the fourth quarter (Carvalho, 1988), while spent individuals are caught up until March (Anon., 2000).

Due to the scarcity of knowledge on the reproductive biology of this species, the main objectives of the present work are:

i) To study the sexual cycle of both males and females from mainland Portugal and Madeira.

ii) To investigate the fecundity type of the black scabbardfish based on four lines of evidence, suggested by Hunter et al. (1992), Greer Walker et al. (1994) and Murua and Saborido-Rey (2003): (1) hiatus between the advanced stock of vitellogenic oocytes and the smaller immature oocytes; (2) mean diameter of the advanced vitellogenic oocytes in the standing stock over the spawning season; (3) number of vitellogenic oocytes in the ovary during the spawning cycle; and (4) level of atresia during spawning.

iii) To estimate total fecundity by weight of female using two methodologies.

iv) To investigate why specimens off mainland Portugal do not spawn. v) To examine the possibility of the occurrence of skipped spawning among the individuals from Madeiran waters.

\section{MATERIAL AND METHODS}

In the early 1990s the presence of another species of the genus Aphanopus (A. intermedius) was detected in the southern northeast Atlantic (Nakamura and Parin, 1993) and more recently in the Azores (Stefanni and Knutsen, 2007) and Madeiran waters, but never in mainland waters (Sara Reis, pers. comm.). These two species are morphologically similar, $A$. intermedius having 102-108 vertebrae and 40-44 dorsal fin spines, compared with 97-100 vertebrae and 38-40 dorsal fin spines in A. carbo (Nakamura and Parin, 1993). To assure that only A. carbo was sampled, an effort was made to determine whether specimens from A. intermedius were present in the samples and every individual morphologically analysed belonged to A. carbo.

Samples were collected on a fortnightly basis at Funchal, Madeira (84 samples) and on a monthly basis at Sesimbra, mainland Portugal (32 samples) from May 2005 to December 2007 (Fig. 1). Over the three years of the project 1479 males and 1732 females were sampled off Madeira, whereas off mainland Portugal 461 males and 488 females were analysed.

For the purpose of the study of the sexual cycle, total length $(\mathrm{cm})$ and total and gutted weights $(\mathrm{g})$ were recorded for each individual. Maturity stages were assigned according to the maturity scale defined by Gordo et al. (2000) (Table 1).

For the remaining objectives, only females were considered. The liver and the ovaries were weighed (cg) and the latter were preserved in a $10 \%$ buffered formaldehyde solution. Slices were taken from the anterior, middle and posterior regions of the ovary, dehydrated with ethanol and embedded in methacrylate. Two sections (3-5 $\mu \mathrm{m})$ were cut from each slice, stained with toluidine blue and digitised using a visual image analysis system (Leica DFC 290). To determine whether the development in the middle region of the ovary was representative of the whole ovary, sections from the three regions were analysed and compared with each other. Since no differences in oocyte size frequency distributions between regions were found, the analysis continued only using middle ovary sections. 

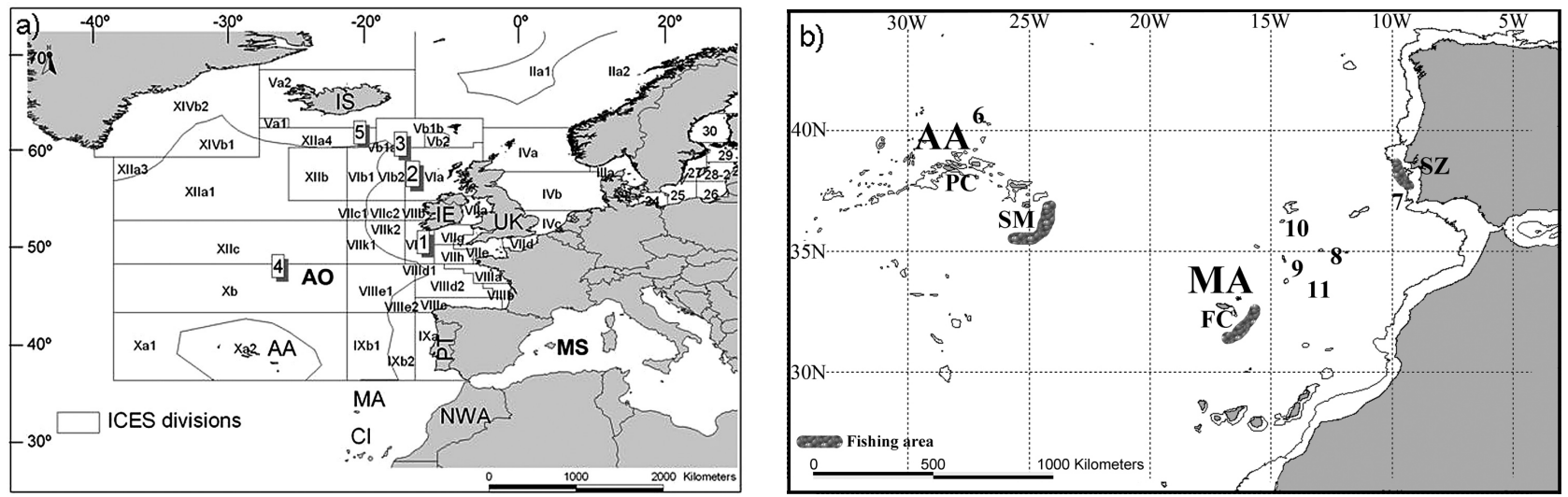

FIG. 1. - a) Map of the northeast Atlantic with the ICES divisions and b) the southern northeast Atlantic with the sampling locations of black scabbardfish and the $1000 \mathrm{~m}$ isobath. AA, Azores Archipelago; AO, Atlantic Ocean; CI, Canary Islands; FC, Funchal; IE, Ireland; IS, Iceland, MA, Madeira Archipelago; MS, Mediterranean Sea; NWA, Northwest Africa; PC, Pico Island; PT, mainland Portugal; SM, Santa Maria Island; SZ, Sesimbra (mainland Portugal); UK, United Kingdom; 1, Porcupine Seabight; 2, Rockall Trough; 3, Hatton Bank; 4, Faraday seamount; 5, Reykjanes Ridge; 6, Sedlo seamount; 7, Gorringe seamount; 8, Ampère seamount; 9, Unicorn bank; 10, Lion seamount; 11, Seine seamount.

To investigate the type of fecundity and estimate total fecundity (second and third goals), only prespawning ovaries without post-ovulatory follicles from females caught off Madeira between September and December (the known spawning season, Figueiredo et al., 2003) in 2006 and 2007 were used. The total number obtained per sampling year was 83 and 84, respectively. To investigate the type of fecundity present in the black scabbardfish, the size frequency distribution of oocytes with a visible nucleus was determined in histological sections of prespawning ovaries (without migratory nucleus stage or post-ovulatory follicles), using the Image-Pro
Plus software. To estimate the changes in size and number of vitellogenic oocytes during the spawning season, pre-spawning and spawning ovaries (without post-ovulatory follicles) were analysed between September and November.

The relative intensity of atresia in yolked oocytes was calculated as the percentage of alpha atresia stage oocytes in the total number of oocytes present in an individual ovary, using the histological sections. In the present work only the alpha atresia stage was counted because the later stages of atresia can be easily confused with other structures such as degenerating post-ovulatory follicles. The prevalence

TABLE 1. - Description of females and males maturity stages for black scabbardfish.

Stage I

Immature

Stage II

Developing

Stage III

Pre-spawning

Stage IV

Spawning

Stage V

Post-spawning
Ovaries small, transparent or translucent and no oocytes can be seen with the naked eye. Previtellogenic oocytes up to $120 \mu \mathrm{m}$.

Larger and thicker ovaries, whitish or pinkish in colour with small opaque oocytes that can be seen with the naked eye. Oocytes up to $320 \mu \mathrm{m}$, the largest characterised by the appearance of cortical alveoli.

Ovaries thicker, yellowish in colour and with oocytes easily distinguishable, predominantly opaque. Oocytes up to $1350 \mu \mathrm{m}$, the largest characterised by the presence of yolk globules

Ovaries occupy the abdominal cavity with the hyaline oocytes dominating and easily extruding under slight pressure on abdomen. Oocytes up to $1550 \mu \mathrm{m}$, the largest suffering completion of yolk coalescence and hydration.

Ovaries flaccid and reddish in colour with residual eggs can be seen with the naked eye. Post ovulatory follicles present.
Firm testes with laminar aspect, translucent or slightly pink. Spermatogonia dominate $(>90 \%)$ although primary spermatocytes can also be found.

Testes white-pinkish in colour and larger than in the previous stage. Seminiferous tubules become distinguishable. Spermatocytes dominate $(\sim 75 \%)$. There are still no spermatozoa present.

Testes white in colour. Sperm can be extruded after pressure on the abdomen. Spermatocytes still dominate but spermatids became more abundant $(>20 \%)$. Spermatozoa are already present.

Testes white in colour. Sperm can be extruded very easily after a slight pressure on the abdomen. Full development of both collecting and sperm ducts which are full of spermatozoa. Seminiferous tubules are also full of spermatid and spermatozoa.

Testes flaccid with a haemorrhagic aspect. No spermatogenesis; some residual spermatozoa in lobules and sperm ducts. 
of alpha atresia, defined as the number of female fish with alpha atresia oocytes as a proportion of the population (Greer Walker et al., 1994), was also investigated.

Total fecundity (the number of yolked oocytes in the ovary-potential fecundity-minus the number of atretic oocytes) was estimated using gravimetric and stereological methods. The gravimetric method is based on the relationship between ovary weight and the oocyte density in the ovary (reviewed in greater detail in Hunter et al., 1989 and Murua et al., 2003). Histological ovary sections were examined at $40 \times$ magnification to select the ovaries to be used in the gravimetric method to ensure that post-ovulatory follicles were not present. In fact, the presence of these follicles indicates that spawning has already begun and the potential fecundity would be underestimated. From each ovary, three subsamples with a weight of approximately $0.04 \mathrm{~g}$ were cut and dried (in order to obtain a minimum of 250 oocytes). The oocytes in the subsamples were counted and measured under a stereomicroscope with a grid, a micrometric eyepiece and 50× magnification.

The stereological method uses the examination of digitised images of histological sections. From histological sections it is possible to distinguish the cells and determine the number of cells in different categories, i.e. oocytes that are either pre-vitellogenic, vitellogenic or atretic. We used images from each histological section and oocytes were counted at a known area of the images. Only oocytes with a visible nucleus were counted from pre-spawning ovaries, using for this purpose the Image-Pro Plus software. To estimate the number of yolked oocytes in the ovary, the stereological method was applied (Emerson et al., 1990).

Analysis of variance-ANOVA $(\alpha=0.05)$-was applied to compare: (i) the fecundity estimates by gravimetric and stereological methods; (ii) the total fecundity estimated per year; (iii) the number of yolked oocytes estimated by spawning season; and (iv) the relative fecundity per maturity stage per year.

To determine why specimens off mainland Portugal do not spawn (fourth goal), only developing females above the length at first maturity $(103 \mathrm{~cm}$, Figueiredo et al., 2003) caught off mainland Portugal and in Madeiran waters were considered for the period from April to November. Developing stage is the latest maturity stage reached by the very large majority of mainland specimens (Figueiredo et al., 2003). The above time period was chosen to guarantee that most females were in the developing, pre-spawning and spawning condition in Madeiran waters. In their ovaries, the nucleated oocytes were measured using the Image-Pro Plus software and the mean oocyte diameter was compared between Madeiran and mainland specimens using Student's $t$ test. Gonadosomatic index (GSI, calculated as the percentage of the ovary weight in relation to the gutted weight), hepatosomatic index (HSI, the percentage of the liver weight in relation to the gutted weight) and Fulton's condition factor $\mathrm{K}$ (K=gutted weight/length ${ }^{3}$ ) were also estimated for mainland and Madeiran females grouped in 5-cm size classes. These indices were then compared for each size class using single-factor analysis of variance.

To analyse the presence of reproductive versus non-reproductive specimens (skipped spawners) in Madeiran waters (fifth goal), only the period from September to November was considered. Females with no opaque oocytes in their ovaries were considered as non-reproductive or skipped spawners (Rideout et al., 2005). The frequency of skipped spawning by year was calculated as the number of non-reproductive females divided by the total number of mature females sampled (Rideout et al., 2006). Fish were grouped into 5-cm size classes in order to compare the frequency of skipped spawning among fish of different size classes. GSI, HSI and $\mathrm{K}$ were also estimated for the reproductive and nonreproductive females grouped in 5-cm size classes. These indices were also compared for each size class using single-factor analysis of variance.

\section{RESULTS}

\section{Sexual cycle}

In females, only the first two maturity stages were observed off mainland Portugal (Fig. 2a). During this study, only one stage III female was sampled, in August 2006. In Madeiran waters, females in all five stages were observed. The distribution of the maturity stages of Madeiran females throughout the year is shown in Figure 3a. Immature females were rare in the samples, whereas the developing females were dominant from April to August. The reproduction period lasted from September to December, with pre-spawning and spawning females prevailing. Post-spawning females appeared from December to March. 


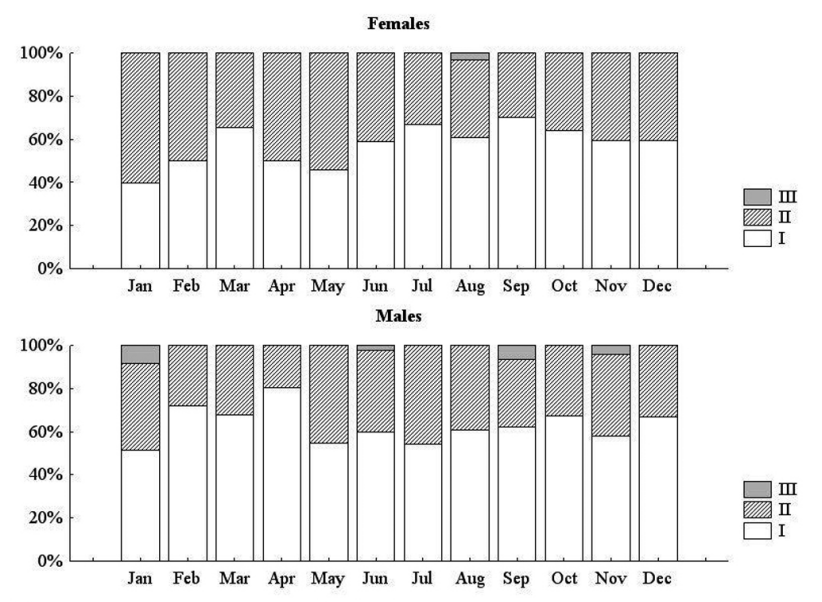

FIG. 2. - Monthly percentages of maturity stages of black scabbardfish from mainland Portugal: females (a) and males (b).

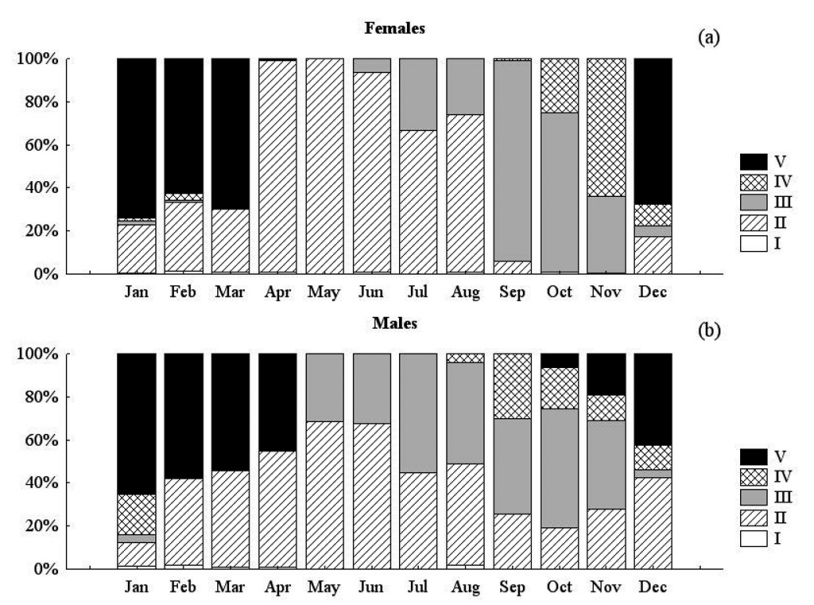

FIG. 3. - Monthly percentages of maturity stages of black scabbardfish from Madeira: females (a) and males (b).

Only the first three stages of males were recorded in mainland waters (Fig. 2b), whereas all five stages were recorded in Madeiran waters. Immature males were rare in Madeiran waters but developing males occurred throughout the year, mainly from March to August (Fig. 3b). Pre-spawning and spawning individuals were more abundant from July to November, whereas post-spawning males occurred mainly from December to April.

\section{Fecundity}

Oocyte size frequency distribution of pre-spawning ovaries is shown in Figure 4. The pre-vitellogenic oocytes constituted $62.6 \%$ of the total number of the oocytes and ranged in diameter from $<0.05$ $\mathrm{mm}$ to $0.35 \mathrm{~mm}$. Vitellogenic oocytes constituted $37.4 \%$ of the total number of the oocytes and ranged from $0.60 \mathrm{~mm}$ to $1.50 \mathrm{~mm}$. The hiatus between pre-

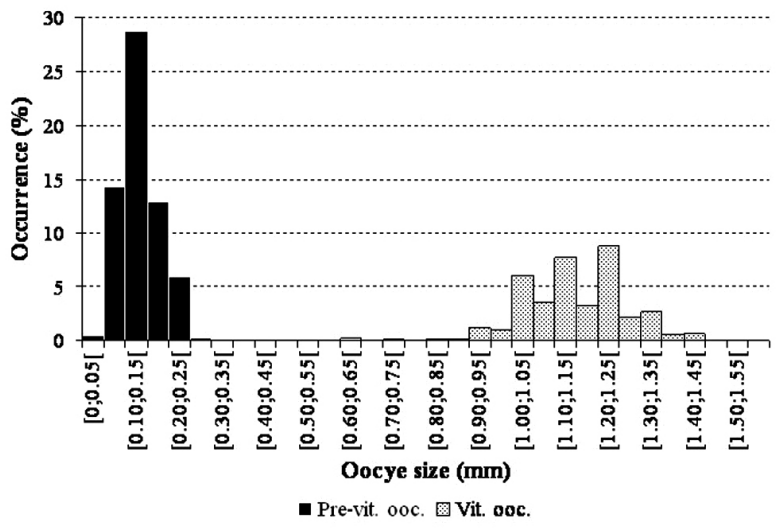

FIG. 4. - Frequency distribution of oocyte size (in $\mathrm{mm}$ ) in prespawning ovaries of black scabbardfish (Pre-vit. ooc., Pre-vitellogenic oocytes; Vit. ooc., Vitellogenic oocytes).

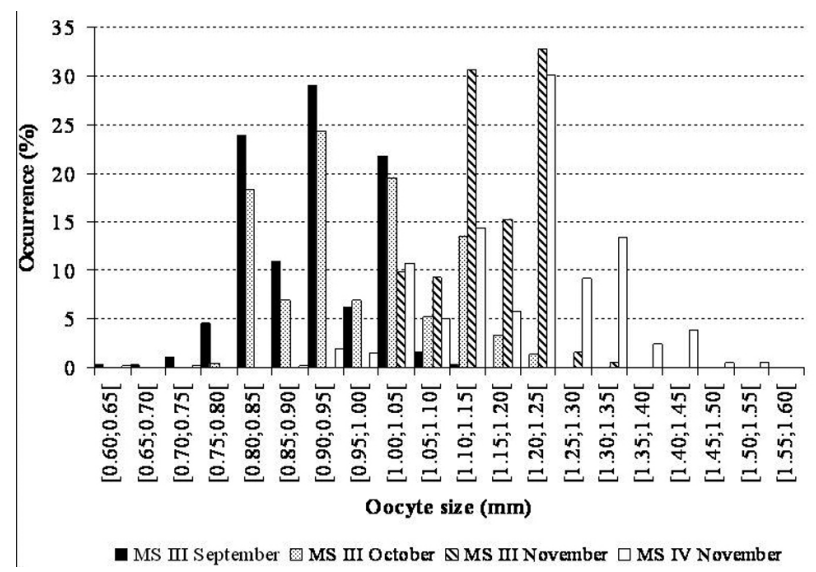

FIG. 5. - Frequency distribution oocyte size (in $\mathrm{mm}$ ) in prespawning and spawning ovaries without post-ovulatory follicles over the spawning season. (MS III September $=$ Maturity stage III in September; MS III October, Maturity stage III in October; MS III November, Maturity stage III in November; MS IV November, Maturity stage IV in November).

vitellogenic and vitellogenic oocytes was present and evident in all ovaries analysed, indicating that the standing stock of advanced yolked oocytes is well defined throughout the spawning season. The presence of this hiatus corroborates the attribution of determinate fecundity to black scabbardfish.

Figure 5 shows the size frequency distribution of the standing stock of advanced vitellogenic oocytes over the spawning season (between September and November) for females in maturity stage III (prespawning) and IV (spawning). The movement of the size distribution to the right is evident, as a result of the increase in oocyte size as the spawning season progresses. These results are also consistent with determinate fecundity.

The number of standing stock of advanced vitellogenic oocytes over the spawning season was also 
TABLE 2. - Prevalence of atresia by maturity stage in black scabbardfish from Madeiran waters in 2006 and 2007.

\begin{tabular}{llccc}
\hline \multirow{2}{*}{ Sampling year } & Maturity stage & Number of fish examined & Number of fish with atretic oocytes & Prevalence of atresia (\%) \\
\hline \multirow{2}{*}{2006} & III - Pre-spawning & 36 & 12 & 33.33 \\
2007 & IV - Spawning & 47 & 19 & 19.15 \\
& III - Pre-spawning & 78 & 1 & 24.36 \\
& IV - Spawning & 6 & 16.67 \\
\hline
\end{tabular}

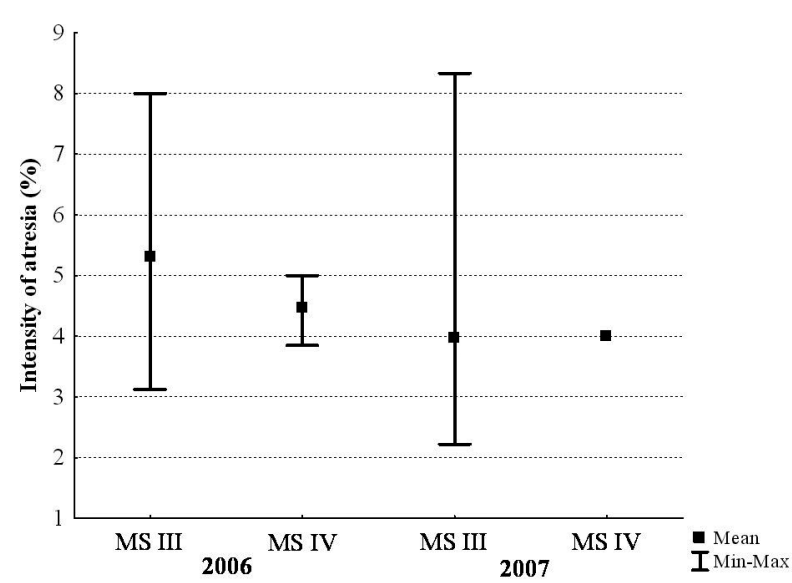

FIG. 6. - Intensity (\%) of atresia in pre-spawning (maturity stage III) and spawning (maturity stage IV) ovaries without post-ovulatory follicles. (MS III, Maturity stage III; MS IV, Maturity stage IV).

estimated and no significant differences were found in the potential fecundity estimated for pre-spawning females between September and November (spawning season $)(p$-value $=0.594)$.

Atresia was present in the two analysed maturity stages but with different levels of incidence (Fig. 6). In 2006, the relative intensity of atresia reached values between $3.13 \%$ and $8.00 \%$ in pre-spawning ovaries and between $3.85 \%$ and $5.00 \%$ in spawning ovaries. In 2007 the relative intensity of atresia in pre-spawning ovaries was between $2.22 \%$ and $8.33 \%$. For spawning ovaries, only one ovary $(4 \%$ of total) with atresia was observed.

The prevalence of atresia was also investigated. Table 2 shows the results obtained for each sampling year and maturity stage analysed. It ranged from $33.33 \%$ in 2006 to $16.67 \%$ in 2007. No significant differences were found between the potential fecundity estimate

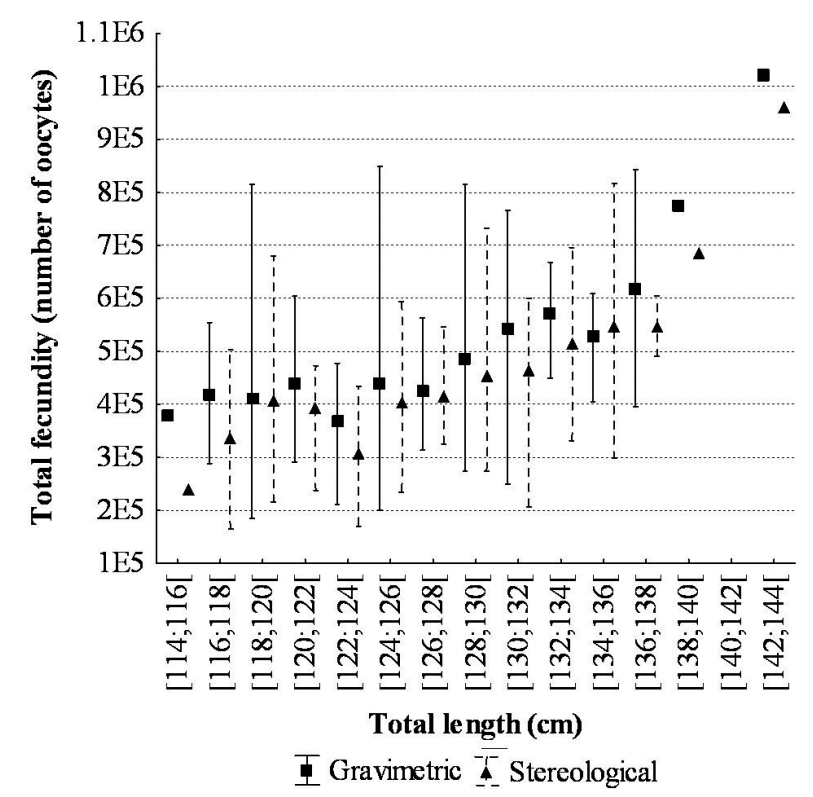

FIG. 7. - Comparison of total fecundity estimates (number of oocytes) (mean, minimum and maximum) obtained by gravimetric and stereological methods, by total length.

and the total fecundity estimate by year ( $\mathrm{p}$-value $=0.819$ and $p$-value $=0.779$ for 2006 and 2007, respectively), which indicates that atresia intensity was low.

Figure 7 shows the total fecundity estimated by gravimetric and stereological methods by total length of female. It is evident that, from class [122; $124[\mathrm{~cm}$, there is a tendency for larger females to show higher mean values of total fecundity, and no apparent trend for smaller length classes. Estimates of total fecundity by gravimetric methods tend to be slightly higher than those based on stereological methods. However, no significant differences were obtained between the gravimetric and the stereological methods ( $p$-value $=0.108)$.

TABLE 3. - Minimum, mean and maximum values of relative fecundity by weight of female estimated by year and maturity stage.

\begin{tabular}{|c|c|c|c|c|c|}
\hline Sampling year & Maturity stage & Number of fish examined & Minimum & $\begin{array}{l}\text { ndity (o } \\
\text { Mean }\end{array}$ & Maximum \\
\hline 2006 & $\begin{array}{l}\text { III - Pre-spawning } \\
\text { IV - Spawning }\end{array}$ & $\begin{array}{l}36 \\
47\end{array}$ & $\begin{array}{l}73 \\
88\end{array}$ & $\begin{array}{l}145 \\
191\end{array}$ & $\begin{array}{l}263 \\
323\end{array}$ \\
\hline 2007 & $\begin{array}{l}\text { III - Pre-spawning } \\
\text { IV - Spawning }\end{array}$ & $\begin{array}{l}78 \\
6\end{array}$ & $\begin{array}{c}86 \\
150\end{array}$ & $\begin{array}{l}169 \\
221\end{array}$ & $\begin{array}{l}373 \\
281\end{array}$ \\
\hline
\end{tabular}




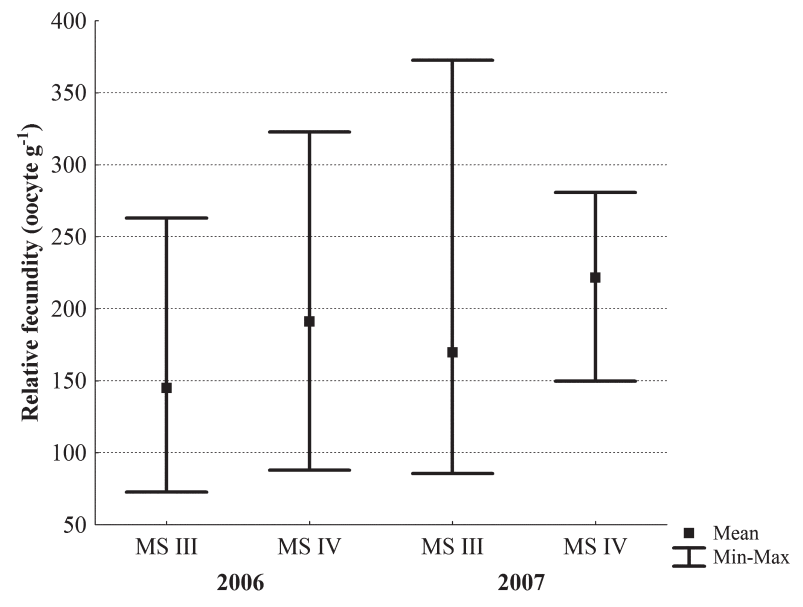

FIG. 8. - Relative fecundity (in oocytes $\mathrm{g}^{-1}$ female weight) estimates in pre-spawning (maturity stage III) and spawning (maturity stage IV) ovaries by sampling year. (MS III, Maturity stage III; MS IV, Maturity stage IV).

Relative fecundity was also estimated as the total number of oocytes by weight of female. Figure 8 shows the range of relative fecundity estimate by sampling year and maturity stage. The lowest value (73 oocytes $\mathrm{g}^{-1}$ ) was recorded in 2006 and the highest ( 373 oocytes $\left.\mathrm{g}^{-1}\right)$ in 2007, both for pre-spawning females (Table 3). Spawning females (maturity stage IV) showed slightly higher mean values of relative fecundity than pre-spawning females, but no significant differences were found.

\section{Reproductive status of females from mainland Portugal}

Developing females occurred mainly in spring in Madeiran waters (Fig. 3a) and all-year round (although in lower percentages during the second semester) in waters of mainland Portugal (Fig. 2a). To investigate the presence of non-reproductive individuals in mainland waters the ovaries from females captured between April and June were analysed. The comparison of the ovaries from females from the two regions showed a significant difference in the mean oocyte size (p-value $<0.001$ ), with Madeiran females showing a higher occurrence of oocytes in the cortical alveoli stage. This difference in the oocyte size was reflected in the GSI, which was significantly ( $\mathrm{p}$-value $<0.05$ ) higher in individuals from Madeiran waters in all but one of the size classes (Fig. 9a). However, significant differences were found in both the HSI and Fulton's condition factor in only one size class (110-115 cm for the HSI), though the HSI was generally higher in Madeiran than in mainland individuals (Fig. 9b and c).

\section{Mainland}

\section{Madeira}

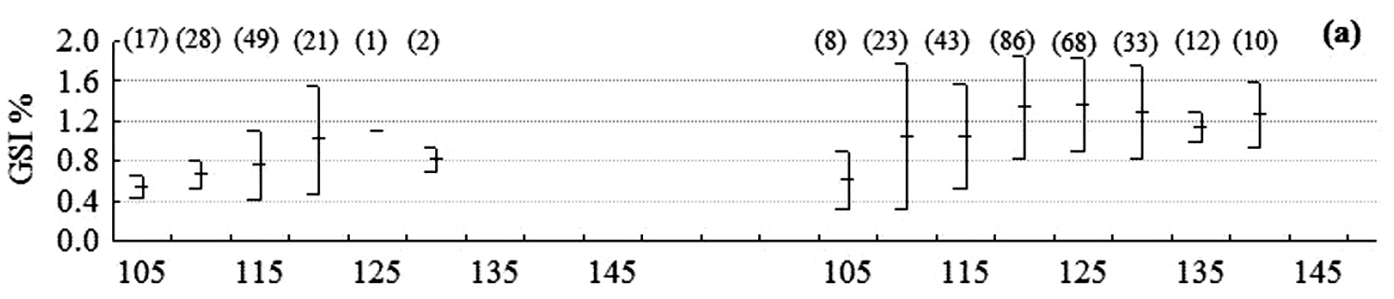

(b)
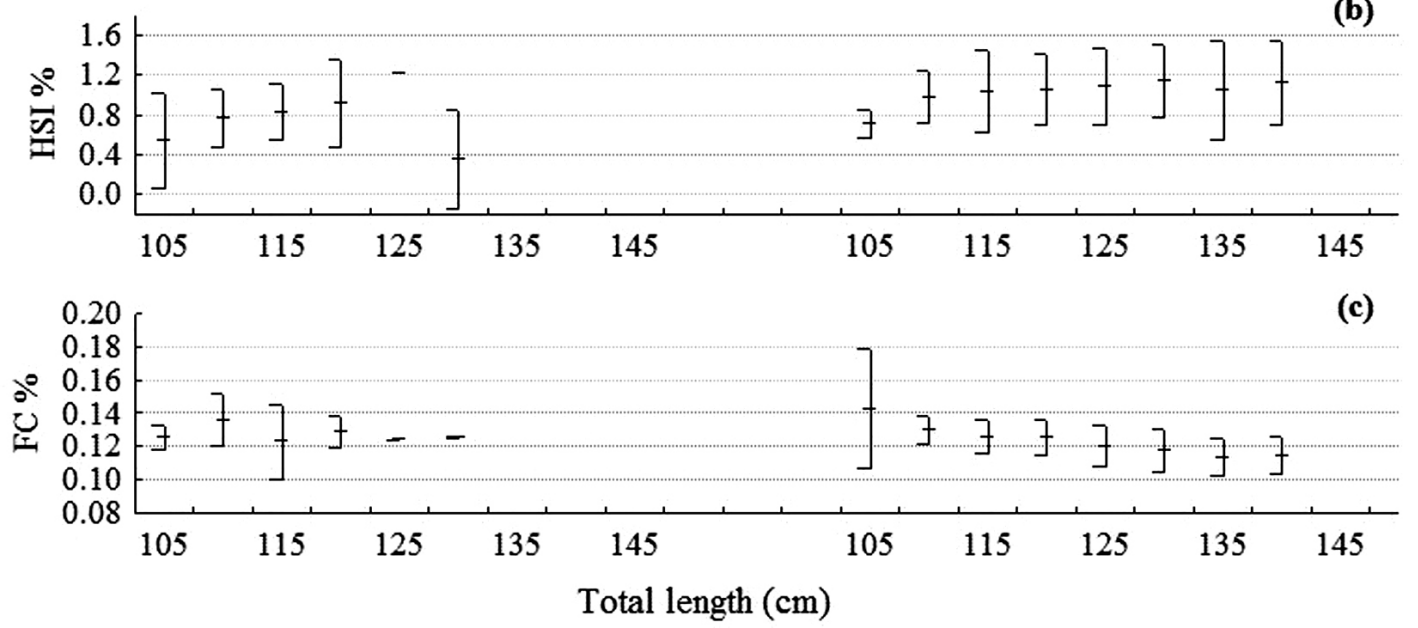

FIG. 9. - Comparison (a) gonadosomatic index (GSI), (b) hepatosomatic index (HSI) and (c) Fulton's condition factor (CF) per 5-cm length class between mainland Portugal and Madeira females. Sample sizes are given in parenthesis. 


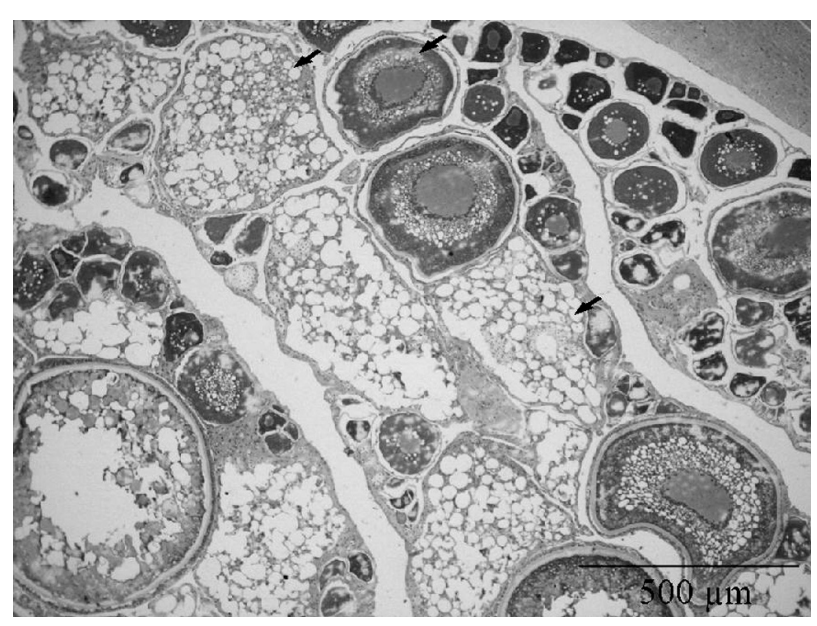

FIG. 10. - Generalised atresia in the oocytes (arrows) of females from mainland Portugal.

From July on, the oocytes of all mainland females began to suffer a generalised atresia (Fig. 10). On the other hand, in Madeiran waters, the reproductive cycle continued and, after the period of yolk accumulation, maturation and ovulation occurred.

\section{Reproductive status of females from Madeira}

In Madeiran waters, the pre-spawning stage lasted mainly from July to October and the ripe condition mainly from October to December, although a few

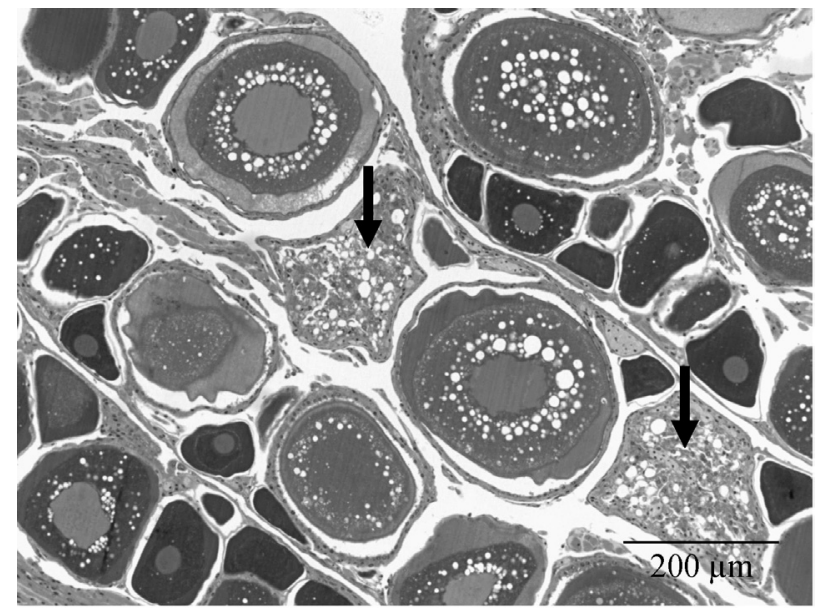

FIG. 11. - Atresia in the oocytes (arrows) of Madeiran non-reproductive females.

individuals could persist in this stage until February (Fig. 3a). However, not all the individuals sampled during the spawning season had ovaries in stages III or IV. In fact, during this 3-year period and in some individuals, gametogenesis was halted and all vitellogenic oocytes were reabsorbed via follicular atresia (Fig. 11). The proportion of non-reproductive fish for the 3-year period was almost $28.0 \%$ and varied from $37.4 \%$ in 2005 to $21.2 \%$ in 2006 (Table 4). These individuals were easily recognised by their GSI, which was significantly ( $\mathrm{p}$-value $<0.05$ ) lower

\section{Reproductive}

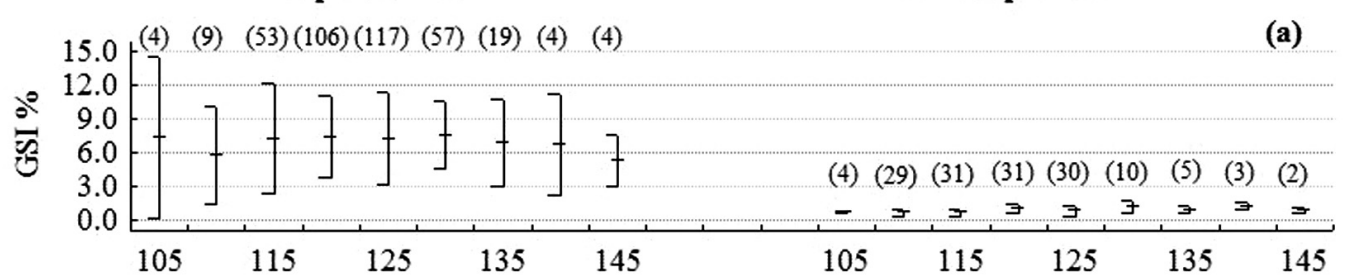

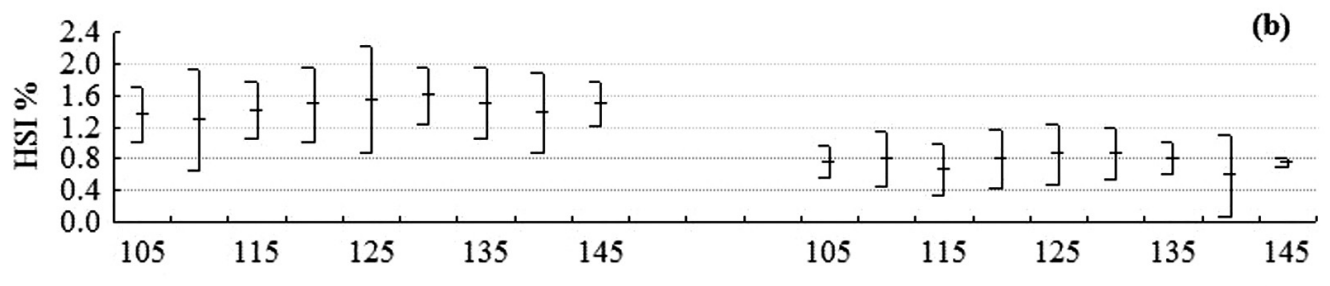

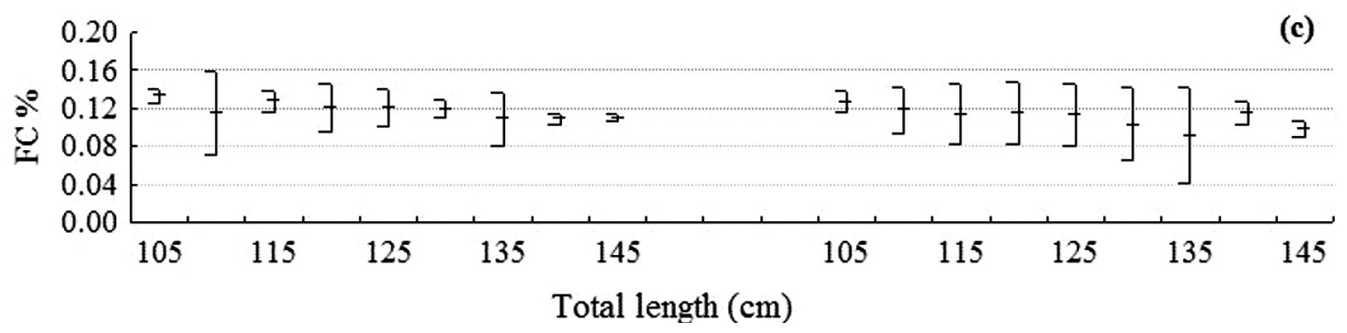

FIG. 12. - Comparison of the (a) gonadosomatic index (GSI), (b) hepatosomatic index (HSI) and (c) Fulton's condition factor (CF) per 5-cm length class between non-reproductive and reproductive females from Madeira. Sample sizes are given in parenthesis 
TABLE 4. - Proportion of non-reproductive female black scabbardfish per size class $(\mathrm{cm})$ and year in Madeiran waters. Sample sizes are given in parenthesis.

\begin{tabular}{lcccr}
\hline Size class & 2005 & 2006 & 2007 & \multicolumn{1}{c}{ All years } \\
\hline 105 & $100.00(1)$ & -- & $42.86(7)$ & $50.00(8)$ \\
110 & $50.00(8)$ & $87.50(8)$ & $81.82(22)$ & $76.32(38)$ \\
115 & $56.00(25)$ & $16.67(24)$ & $37.14(35)$ & $36.90(84)$ \\
120 & $31.71(41)$ & $20.00(40)$ & $17.86(56)$ & $22.63(137)$ \\
125 & $31.25(32)$ & $14.29(35)$ & $18.75(80)$ & $20.41(147)$ \\
130 & $20.00(10)$ & $11.54(26)$ & $16.13(31)$ & $14.93(67)$ \\
135 & $40.00(5)$ & $14.29(7)$ & $16.67(12)$ & $20.83(24)$ \\
140 & -- & $66.67(3)$ & $25.00(4)$ & $42.86(7)$ \\
145 & $0.00(1)$ & $33.33(3)$ & $50.00(2)$ & $33.33(6)$ \\
All sizes & $37.40(123)$ & $21.23(146)$ & $27.31(249)$ & $27.99(518)$ \\
\hline
\end{tabular}

than that of fish preparing for spawning (Fig. 12a). Furthermore, the HSI was also significantly (p-value $<0.05$ ) lower in non-reproductive individuals in all but one of the size classes (Fig. 12b). A comparison of the Fulton's condition factor between reproductive and non-reproductive females showed that, although it was generally smaller in non-reproductive individuals (Fig. 12c), no significant differences were found in the majority of the size classes.

Non-spawning individuals were present in all size classes although their proportion was higher among the smaller size classes, 105 to $115 \mathrm{~cm}$ (Table 4).

\section{DISCUSSION}

Aphanopus carbo can be found in the NE Atlantic from Iceland to the south of Madeira Island (Gordon, 1986; Merrett et al., 1991). However, mature individuals were only caught in Madeiran waters (Figueiredo et al., 2003) and, more recently, off the Canary Islands (Pajuelo et al., 2008) and the northwest coast of Africa (Perera, 2008). Moreover, only two individuals with ripe gonads were cited by Ehrich (1983) in Porcupine Bank and Magnússon and Magnússon (1995) found specimens in spent condition in Icelandic waters.

Four main criteria were used to describe the type of fecundity (Hunter et al., 1992; Greer Walker et al., 1994 and Murua and Saborido-Rey, 2003): (a) size frequency distribution; (b) mean diameter of the advanced vitellogenic oocytes; (c) number of vitellogenic oocytes; and (d) atresia.

The presence of a distinct hiatus in the oocyte size frequency distribution between pre-vitellogenic and vitellogenic oocytes is generally associated with determinate fecundity and the absence of such hiatus is usually related to indeterminate fecundity. In the present study, the analysis of oocyte size frequency distribution in ovaries without post-ovulatory follicles showed that there was a clear hiatus between pre-vitellogenic and vitellogenic oocytes. This fact strongly suggests that black scabbardfish has a determinate fecundity strategy.

The advanced vitellogenic oocytes increased in size over the spawning season and no significant differences were observed in the number of vitellogenic oocytes in pre-spawning females. These facts also suggest that black scabbardfish has a determinate fecundity, because no new yolked oocytes are recruited to replace those that have been shed during the spawning season. In fishes with indeterminate fecundity, it is expected that the size of the advanced vitellogenic oocytes does not increase (it may remain constant or decrease) over the spawning season due to the recruitment of new oocytes (de novo vitellogenesis) (Murua and Saborido-Rey, 2003).

Atresia is a potential source of error for fecundity estimates (Hunter et al., 1992; Cooper et al., 2005), although atretic oocytes can be easily identified and estimated with the stereological method. According to Hunter et al. (1992), in fish with determinate fecundity, the intensity of atresia is rarely generalised and if present, it is distributed sparsely over the spawning season. Moreover, low levels of intensity of atresia usually characterise determinate spawners and do not seem to have a greater effect on the potential fecundity (Hunter et al., 1992; Murua and Saborido-Rey, 2003). However, studying the Norwegian spring-spawning herring, a species with determinate fecundity, Kurita et al. (2003) found that the level of fecundity reduction was particularly high $(56 \%)$ in comparison with that of other species. In the present work the prevalence of atresia attained 33\% in pre-spawning females, but the intensity of atresia was rather low in both pre-spawning and spawning females. This value of prevalence of atresia is low when compared with those attained for other species with determinate fecundity like the herring (Kurita et al., 2003).

Fecundity estimates will be biased if the sampling is done either too early or too late in the spawning season. If the sampling is done too early, the advanced stock of oocytes may not have matured enough to be completely separate from the smaller immature oocytes, and consequently estimates may be imprecise or biased. If it is done too late, spawning will have begun, the stock of advanced oocytes 
will have been reduced, and the potential fecundity will be underestimated (Hunter et al., 1989). In this study, this sampling problem did not occur because we always confirmed the presence of post-ovulatory follicles and excluded from the fecundity estimates the ovaries in which such follicles were present.

In the present study, no significant differences were found between fecundity estimates by gravimetric and stereological methods. However, the stereological method seemed to be better for fecundity estimates than the gravimetric method, due to: (a) the ability to distinguish vitellogenic oocytes from non-vitellogenic oocytes at an early stage of ovary development (impossible with the gravimetric method); (b) the fact that the atretic oocytes can be counted and subtracted from potential fecundity estimates; and (c) the fact that post-ovulatory follicles can be identified and quantified (Emerson $e t$ $a l .$, 1990). The need to prepare histological sections may seem to be a disadvantage of the stereological method, but histological sections are always necessary to determine the extent of atresia and the presence of post-ovulatory follicles.

Fecundity estimates are essential to calculate spawning stock biomass (Gordo et al., 2008). In this context, it is important to have an estimate of the annual realised fecundity, i.e. the number of ovulated oocytes spawned in a year by each female. In species with determinate fecundity, this estimate corresponds to the number of vitellogenic oocytes minus the number of oocytes reabsorbed because of atresia. The black scabbardfish shows a relative fecundity ranging from 73 to 373 oocytes $\mathrm{g}^{-1}$ female. Based on the findings following the application of the four main criteria mentioned above, it is most likely a determinate spawner.

Regarding the presence of non-reproductive individuals, it is usually assumed that iteroparous teleost fishes spawn annually when they reach sexual maturity but the occurrence of skipped spawning is being more frequently reported for several fish species (e.g. Walsh and Bowering, 1981; Burton, 1991; Ramsay and Witthames, 1996; Burton et al., 1997). In fact, as Rideout et al. (2005) point out, the scarcity of reports of non-annual spawning does not necessarily reflect the rarity of this condition but rather may be a consequence of the difficulty in identifying post-mature non-reproductive individuals.

According to Rideout et al. (2005), the omission of spawning can be identified by the external appearance of the gonads, the size of the gonads relative to the rest of the body, and the histological appearance of the gonads. These authors report that the GSI and the minimum size at first maturity can be a quick means of identifying a spawning omission: all fish larger than that minimum size and having a GSI below a certain value can be considered to be nonreproductive. A low GSI does not, however, always imply immaturity (since it can also apply to partially spent or spent fish) and, in fact, GSI fluctuates in somewhat different ways in different species, according to the type/mode of spawning (Kainge et al., 2007). However, among the three methods that can be used to test spawning omission, the histological examination of ovaries is the most accurate means of identifying non-reproductive individuals.

In the present work we used both the GSI and histology to investigate why the individuals caught off mainland Portugal do not spawn and the presence of non-reproductive individuals in Madeiran waters. There is emerging evidence that there is a critical window during early vitellogenesis which is highly influential for the decision to spawn or not to spawn (Skjæraasen et al., 2007). In the black scabbardfish the developing stage (characterised by the appearance of cortical alveoli) seems to be that critical window since significant differences occurred in the GSI between the individuals from Madeira and the mainland in that stage. However, these differences could not be seen in either the HSI or Fulton's condition factor. It appears that, in that stage, the stored energy does not differ greatly between future non-reproductive and reproductive individuals or that the stored energy has not yet been utilised for reproductive purposes.

Therefore, the absence of reproductive specimens in mainland Portugal may be due to: (i) the cessation of gametogenesis with the reabsorption of all vitellogenic oocytes via follicular atresia, which may be related to a continuous poor nutritional condition or a different diet; or (ii) a migration of individuals in better condition to other areas to spawn. Regarding the first possibility, data from Atlantic cod showed that high levels of non-reproductive individuals might be related to low abundance of their main prey-juvenile redfish in the case of the Flemish Cap cod (Walsh et al., 1986) and capelin in the case of the Barents Sea cod (Kjesbu et al., 1998). Unfortunately, the information available for the diet of black scabbardfish is limited (Mauchline and Gordon, 1984) since the percentage of empty stomachs can be as high as $93 \%$ (Freitas, 1998). 
Concerning the second possibility, new spawning areas have been found very recently in the Canary Islands (Pajuelo et al., 2008) and near the northwest coast of Africa (Perera, 2008) in addition to Madeiran waters, the previously known spawning area of black scabbardfish (Figueiredo et al., 2003). Therefore, it is possible that a spawning migration of the individuals with better condition may occur to one of these known areas in the southern northeast Atlantic. The fish in poorer condition would remain off mainland Portugal and might interrupt reproductive development in successive years and thus increase in length but never have spawned (i.e. they are still technically immature). Pawson et al. (2000) reported that full maturity and spawning in female sea bass may not occur until they grow to a length greater than $42 \mathrm{~cm}$ and remain in water above $10^{\circ} \mathrm{C}$ during the main period of gonad development, and these conditions may be achieved through migrations between relatively warm waters. Furthermore, fish that do not meet these conditions maintain their virgin state, entering the largest oocyte cohort in atresia.

The presence of non-reproductive individuals in Madeiran waters may indicate the occurrence of skipped spawning. This hypothesis can only be confirmed by the existence of old POFs in the ovaries of non-reproductive females (confirming that these fish had already spawned in the past). On the other hand, the absence of POFs in our samples could be due to a quicker reabsorption of the follicles at higher and more stable water temperature, which can reach $11^{\circ} \mathrm{C}$, when compared with species living in colder waters, which maintain the POFs for several months (e.g. Atlantic cod as reported by Saborido-Rey and Junquera (1998) and Rideout et al. (2000)).

It is known that non-reproductive individuals tend to be in poorer condition and have a lower hepatosomatic index than fish that are successfully ripening (Burton and Idler, 1984; Rideout et al., 2000). It is possible that the liver of the black scabbardfish plays a very important role in the success of maturation based on the difference found in the HSI between non-reproductive and ripening individuals. The liver could be the primary source of energy, with muscle being the secondary source. This could explain the absence of differences in the condition factor found at the beginning of the spawning season between non-reproductive and ripening individuals. However, according to Jørgensen et al. (2006), poor individual condition at the beginning of a spawning season can be either a cause or an effect of skipped spawning and if spawning is skipped then the best option should be to give priority to somatic growth, keeping energy reserves at a moderate level and resulting in a low condition factor. This poor condition would then be an effect of skipped spawning and thus hard to separate from poor condition stemming from low food availability, which could lead to skipped spawning.

Skipped spawning may be related to fish size, since the highest percentage of non-reproductive individuals was observed in the smallest length classes. The same observation was made by Jørgensen et al. (2006) in the cod and Engelhard and Heino (2005) in the Atlantic herring. The former reported that smaller cod needed full energy stores to spawn, whereas larger cod also spawned when less energy was stored. The latter also noticed this behaviour in second-time spawners that frequently skipped spawning. Rideout and Rose (2006) also reported the greatest proportion of non-reproductive fish in the smallest size class of potential spawners in Atlantic cod. This situation may be related to the individual's growth trajectory (Jørgensen et al., 2006): first, only somatic growth takes place up to the age at sexual maturation; second, growth is balanced with reproduction for several years following maturation (growth taking precedence when spawning is skipped more frequently); and third, after that, reproduction receives the full allocation of energy and the frequency of skipped spawning stabilises. In the case of skipped spawning and in a fish that has already achieved sexual maturity, the probability of spawning in the upcoming season is less dependent on size and more dependent on the amount of energy stored in the liver and available to be allocated to gonad and gamete development (Rideout et al., 2006).

In black scabbardfish, the percentage of nonreproductive females varied between $21.23 \%$ and $37.40 \%$ which means that, in the future and in terms of upcoming management, it will be very important to analyse the extent of skipped spawning in order to prevent an overestimate of the population's reproductive potential that could lead to erroneous assessment estimates with severe consequences for management options.

\section{ACKNOWLEDGEMENTS}

We would like to thank Joana Vasconcelos and Sara Reis for providing gonads from Madeira archi- 
pelago and to Dr John Gordon for revising the English. The manuscript was greatly improved by the comments of three anonymous referees. This study was partially supported by Fundação para a Ciência e Tecnologia (project POCTI/CVT/46851/2002).

\section{REFERENCES}

Anon. - 2000. Environment and biology of deep-water species Aphanopus carbo in the NE Atlantic: basis for its management (BASBLACK). Final Report of EU Study Project 97/0084.

Begg, G.A. - 1998. Reproductive biology of school mackerel (Scomberomorus queenslandicus) and spotted mackerel $(S$. munroi) in Queensland east-coast waters. Mar. Freshw. Res., 49: 261-270.

Burton, M.P.M. - 1991. Induction and reversal of the non-reproductive state in winter flounder, Pseudopleuronectes americanus Walbaum, by manipulating food availability. J. Fish Biol., 39: 909-910.

Burton, M.P.M. and D.R. Idler. - 1984. The reproductive cycle in winter flounder, Pseudopleuronectes americanus Walbaum. Can. J. Zool., 62: 2563-2567.

Burton, M.P.M., R.M. Penney and S. Biddiscombe. - 1997. Time course of gametogenesis in Northwest Atlantic cod (Gadus morhua). Can. J. Fish. Aquat. Sci. 54(Suppl. 1): 122-131.

Carvalho, D. - 1988. Relatório final do estudo efectuado sobre o peixe-espada preto (Aphanopus carbo, Lowe, 1839) capturado na ZEE da Madeira. EC Report. DG XIV/CE Doc. No. $\mathrm{XIV} / \mathrm{B} / 1-1987,177 \mathrm{p}$.

Cooper, D.W., K.E. Pearson and D.R. Gunderson. - 2005. Fecundity of shortspine thornyhead (Sebastolobus alascanus) and longspine thornyhead (S. altivelis) (Scorpaenidae) from the northeastern Pacific Ocean, determined by stereological and gravimetric techniques. Fish. Bull., 103: 15-22.

Ehrich, S. - 1983. On the occurrence of some fish species at the slopes of the Rockall Trough. Arch. Fischereiwiss., 33(3): 105-150.

Emerson, L.S., M. Greer Walker and P.R. Witthames. - 1990. A stereological method for estimating fecundity. J. Fish. Biol., 39: 721-730.

Figueiredo, I., P. Bordalo-Machado, S. Reis, D Sena-Carvalho, T. Blasdale, A. Newton and L.S. Gordo. - 2003. Observations on the reproductive cycle of the black scabbardfish (Aphanopus carbo Lowe, 1839) in the NE Atlantic. ICES J. Mar. Sci., 60: 774-779.

Freitas, I. - 1998. Contribuição para o conhecimento da ecologia alimentar do peixe-espada preto, Aphanopus carbo Lowe, 1839 (Pisces: Trichiuridae), no arquipélago da Madeira. Relatório de estágio do curso de biologia, Universidade da Madeira.

Gordo, L.S., A. Costa, P. Abaunza, P. Lucio, A.T.G.W. Eltink and I. Figueiredo. - 2008. Determinate versus indeterminate fecundity in horse mackerel. Fish. Res., 89: 181-185.

Gordo, L.S., D. Sena-Carvalho, I. Figueiredo, S. Reis, P. BordaloMachado, A. Newton and J. Gordon. - 2000. Escala de maturação sexual do peixe-espada preto: uma abordagem macro e microscópica. The sexual maturity scale of black scabbardfish: a macro- and microscopic approach. Celta Editora, Oeiras.

Gordon, J.D.M. - 1986. The fish populations of the Rockall Trough. Proc. R. Soc. Edinburgh, 88B: 191-204

Greer Walker, M., P.R. Witthames and J.I. Bautista de los Reis. 1994. Is the fecundity of the Atlantic mackerel (Scomber scombrus) determinate? Sarsia, 79: 13-26.

Hunter, J.R. and B.J. Macewicz. - 1985. Rates of atresia in the ovary of the captive and wild northern anchovy Engraulis mordax. Fish. Bull., 83(2): 119-136.

Hunter, J.R., B.J. Macewicz and C.A. Kimbrell. - 1989. Fecundity and other aspects of the reproduction of sable fish, Anoplopoma fimbria, in Central California waters. Calif. Coop. Ocean. Fish. Invest. Rep., 30: 61-72.

Hunter, J.R., B.J. Macewicz, N.C.H. Lo and C.A. Kimbrell. - 1992. Fecundity, spawning and maturity of female Dover Sole, Microstomus pacificus, with an evaluation of assumptions and precision. Fish. Bull., 90: 101-128.
Jørgensen, C., B. Ernande, Ø. Fiksen and U. Dieckmann. - 2006. The logic of skipped spawning in fish. Can. J. Fish. Aquat. Sci., 63: 200-211.

Kainge, P., O.S. Kjesbu, A. Thorsen and A.G. Salvanes. - 2007. Merluccius capensis spawn in Namibian waters, but do $M$. paradoxus? Afr. J. Mar. Sci., 29: 379-392.

Kjesbu, O.S., P.R. Witthames, P. Solemdal and M. Greer Walker. 1998. Temporal variations in the fecundity of Arcto-Norwegian cod (Gadus morhua) in response to natural changes in food and temperature. J. Sea Res., 40: 303-321.

Kurita, Y., S. Meier and O.S. Kjesbu. - 2003. Oocyte growth and fecundity regulation by atresia of Atlantic herring (Clupea harengus) in relation to body condition throughout the maturation cycle. J. Sea Res., 49: 203-219.

Magnússon, J.V. and J. Magnússon. - 1995. The distribution, relative abundance, and biology of the deep-sea fishes of the Icelandic slope and Reykjanes Ridge. In: A.G. Hopper (ed.), Deepwater fisheries of the North Atlantic oceanic slope, pp. 161-199. NATO ASI Ser. Kluwer Academic Publishers, Dordrecht.

Marteinsdottir, G., A. Gudmundsdottir, V. Thorsteinson and G. Stefánsson. - 2000. Spatial variation in abundance, size composition and viable egg production of spawning cod (Gadus morhua L.) in Icelandic waters. ICES J. Mar. Sci., 57: 824-830.

Maucline, J. and J.D.M. Gordon. - 1984. Occurrence and feeding of berycomorphid and percomorphid teleost fish in the Rockall Trough. J. Cons., 41: 239-247.

Merrett, N.R., J.D.M. Gordon, M. Stehmann and R.L. Haedrich. 1991. Deep demersal fish assemblage structure in the Porcupine Seabight (eastern North Atlantic): slope sampling by three different trawls compared. J. Mar. Biol. Ass. UK, 71: 329-358.

Murua, H. and F. Saborido-Rey. - 2003. Female reproductive strategies of marine fish species of the North Atlantic. J. Northwest Atl. Fish. Sci., 33: 21-33.

Murua, H., G. Kraus, F. Saborido-Rey, P.R. Witthames, A. Thorsen and S. Junquera. - 2003. Procedures to estimate fecundity of marine fish species in relation to their reproductive strategy. $J$. Northwest Atl. Fish. Sci., 33: 33-54.

Nakamura, I. and N.V. Parin. - 1993. FAO species catalogue. Vol 15. Snake mackerels and cutlassfishes of the world (families Gempylidae and Trichiuridae). An annotated and illustrated catalogue of the snake mackerels, snoeks, escolars, gemfishes, sackfishes, domine, oilfishes, cutlassfishes, scabbardfishes, hairtails and frostfishes known to date. FAO Fish. Synop., 125 (15): 1-136.

Pajuelo J.G., J.A. González, J.I. Santana, J.M. Lorenzo, A. GarcíaMederos and V. Tuset. - 2008. Biological parameters of the bathyal fish black scabbardfish (Aphanopus carbo Lowe, 1839) off the Canary Islands, Central-east Atlantic. Fish. Res., 92: 140-147.

Pawson, M.G., G.D. Pickett and P.R. Whitthames. -2000 . The influence of temperature on the onset of first maturity in sea bass. J. Fish Biol., 56: 319-327.

Perera, C. B. 2008. Distribution and biology of black scabbardfish (Aphanopus carbo Lowe, 1839) in the Northwest of Africa. Ms Thesis, Sciences Faculty, University of Lisbon.

Pianka, E.R. - 2000. Evolutionary ecology. Sixth Edition. BenjaminCummings, Addison-Wesley-Longman. San Francisco.

Ramsay, K. and P. Witthames. - 1996. Using oocyte sizes to assess seasonal ovarian development in Solea solea (L.). J. Sea Res., 36: $275-283$.

Rideout, R.M. and G.A. Rose. - 2006. Suppression of reproduction in Atlantic cod (Gadus morhua L.). Mar. Ecol. Prog. Ser., 320: 267-277.

Rideout, R.M., M.P.M. Burton and G.A. Rose. - 2000. Observations on mass atresia and skipped spawning in northern Atlantic cod, from Smith Sound, Newfoundland. J. Fish Biol., 57: 1429-1440.

Rideout, R.M., G.A. Rose and M.P.M. Burton. - 2005. Skipped spawning in female iteroparous fishes. Fish and Fisheries, 6: 50-72.

Rideout, R.M., M.J. Morgan and G.R. Lily. - 2006. Variation in the frequency of skipped spawning in Atlantic cod (Gadus morhua) off Newfoundland and Labrador. ICES J. Mar. Sci., 63: $1101-1110$

Saborido-Rey, F. and S. Junquera. - 1998. Histological assessment of variations in sexual maturity of cod (Gadus morhua L.) at the Flemish Cap (north-west Atlantic). ICES J. Mar. Sci., 55: 515-521. 
Skjæraasen, J.E., J. Kennedy, A. Thorsen, R. Nash and O.S Kjesbu. - 2007. Timing and determination of skipped spawning in Atlantic cod. Joint NAFO/ICES/PICES Symposium on "Reproductive and Recruitment Processes of Exploited Marine Fish Stocks" 1-3 October, Lisbon, Portugal.

Stefanni, S. and H. Knutsen. - 2007. Phylogeography and demographic history of the deep-sea fish Aphanopus carbo (Lowe, 1839) in the NE Atlantic: vicariance followed by secondary contact or speciation? Mol. Phyl. Evol., 42: 38-46.

Swan, S.C., J.D.M. Gordon and T. Shimmield. - 2003. Preliminary investigations on the uses of otolith microchemistry for stock discrimination of the deep-water black scabbardfish (Aphanopus carbo) in the Northeast Atlantic. J. Northw. Atl. Fish. Sci., 31: 221-231

Trippel, E.A. - 1999. Estimation of stock reproductive potential: history and challenges for Canadian Atlantic gadoid stock assessments. J. Northw. Atl. Fish. Sci., 25: 61-81.

Tucker, D.W. and G. Palmer. - 1949. New British records of two rare deep-sea fishes: Oxynotus paradoxus Frade and Aphanopus carbo Lowe. Nature, 164: 930-931.

Walsh, S.J. and W.R. Bowering. - 1981. Histological and visual observations on oogenesis and sexual maturity in Greenland halibut off northern Labrador. NAFO Sci. Counc. Stud., 1: 71-75.

Walsh, S.J., R. Wells and S. Brennan. - 1986. Histological and visual observations on oogenesis and sexual maturity of Flemish Cap female cod. NAFO Sci. Counc. Res. Doc. 86/111, 11 p.

Scient. ed.: M.P. Olivar.

Received December 12, 2008. Accepted September 28, 2009.

Published online December 22, 2009. 